\title{
Occupational risk assessment of passenger bus drivers
}

\author{
Nataliia Borodina ${ }^{1}$ A; Serhii Cheberiachko ${ }^{2}$ B; Oleg Deryugin ${ }^{3}$ B; \\ Olena Tretyak ${ }^{4}$ B; Ivan Bas ${ }^{5}$ B \\ A Bilotserkivsky Institute of Continuous Professional Education, 54/2, Levanevskjgo, str., Bila Tserkva, 09100, Ukraine \\ B Dnipro University of Technology, 19, Dmytra Yavornytskoho ave., Dnipro, 49005, Ukraine
}

Received: March 29, 2021 | Revised: April 18, 2021 | Accepted: April 30, 2021

DOI: $10.33445 /$ sds.2021.11.2.8

\begin{abstract}
The aim of this work is improving the procedure for professional risk assessment of passenger bus drivers, taking into account ergonomic, psychosocial, individual, and hygienic factors.

To develop the methodology for assessing the professional risk of drivers the theory of analysis was used, which allows to establish alternative solutions of the problem by determining an integrated criterion that depends on a number of individual indicators characterized by ergonomic, psychosocial, individual, and hygienic factors influencing the working conditions of the passenger bus driver.

A checklist has been developed to quickly assess the occupational risk of passenger bus drivers, which takes into account the impact of several harmful production factors that contribute to the creation of unfavorable conditions for the occurrence of occupational diseases. A feature of this approach is the ability to distinguish the level of risk for each harmful production factor and determine the overall level of occupational risk. It is recommended to reduce the effect of occupational risk on the driver of a passenger bus to improve the system of medical examinations, the system of admission to the vehicles driving in the implementation of passenger traffic and strengthen control over the technical condition of vehicles.

The relationship between the integrated criterion of occupational risk of the driver and indicators that are characterized by ergonomic, psychosocial, individual, and hygienic factors, which are formed by the working conditions of the driver in the carriage of passengers.

As a result, a new approach (checklist) is proposed, which can be used in trucking companies without any additional equipment after training in testing.
\end{abstract}

Key words: occupational risk, passenger bus driver, harmful production factors.

\section{Introduction}

The driver's state of health is the main condition for accident-free professional activity. A number of psychological and psychophysiological factors determines the reliability of the driver due to human temperament, the ability to make effective decisions in complex road situations in conditions of time deficit. Human errors due to health disorders, peculiarities of psychological and psychophysiological reactions of the driver is a cause of road traffic accidents (RTA) (Lococo K.H.,
Stutts J., Sifrit K.J., Staplin, L., 2017).

Emotionally stressful work of a passenger bus (PB) driver, in combination with the influence of various harmful factors (noise, general vibration, microclimate parameters), entails the occurrence of occupational diseases. According to the results of medical examinations of PB drivers (Lebedeva T.L., Gurov S.V., Petrov V.A., Chorny Yu.O., 2016), it was found that the frequency of pathology reaches $70 \%$. Each driver with more than 10 years

\footnotetext{
${ }^{1}$ Doctor of Technical Science (D.Sc.), Senior Researcher, professor of department, e-mail: ignsborodina@gmail.com, ORCID: 0000-0002-5942-5658

${ }^{2}$ Corresponding author: Doctor of Technical Science (D.Sc.), Professor of the Department, e-mail: sicheb@ukr.net, ORCID: 0000-0003-3281-7157

${ }^{3}$ Candidate of Technical Science (PhD), Associate Professor of the Department, e-mail: oleg.kot@meta.ua, ORCID: 0000-0002-2456-7664

${ }^{4}$ Candidate of Technical Science (PhD), Associate Professor of the Department, e-mail: elena.novikova.ut@ukr.net, ORCID: 0000-0002-6991-0235

${ }^{5}$ Graduate student of the Department of Labor Protection and Civil Safety, e-mail: ivan.bass2015@gmail.com, ORCID: 0000-0003-0496-4379
} 
of work experience may have 2-3 chronic occupational diseases, the most common of which are: musculoskeletal, cardiovascular and digestive system diseases. A significant number of drivers suffer from radiculitis and radiculopathy of the transverse-sacral spine (Deryugin O. V., Cheberyachko S. I., Tretyak O. O., Cheberyachko, I. M., 2018).

The problems described above are the consequences of the impact of occupational hazards that arise during the driver's work in transport, affecting his psycho-physiological state, his health, his sense of comfort, etc.

Due to the impossibility to eliminate occupational hazards of harmful factors of the production environment, prevention of their adverse effects on drivers is of particular importance, which would allow setting an appropriate work and rest mode according to the requirements (Golinko V., Cheberyachko S., Deryugin O., Tretyak O. Dusmatova, O., 2020; Council Directive 89/391/EEC), which establish the basic principles of preventing hazards by assessing occupational hazards when carrying out transport operations. Therefore, from the above analysis we can conclude that an important role is played by comprehensive awareness of drivers to form a priority attitude to their own health, minimize factors of occupational risk of development of pathology of the cardiovascular system, the formation of the concept of "culture of work".

One of the widespread professional diseases of drivers is the musculoskeletal system disorder. Therefore, the task of assessing ergonomic risks when driving a car is considered in a number of recently published works. In particular, key factors that increase the likelihood of disease have been identified, which include gender, age (Feng Z., Zhan J., Wang C., Ma C., Huang, Z., 2018), body mass index (Mestry S., Shroff R., 2018), physical exercise (Yosef T., Belachew A., Tefera, Y., 2019) working posture at the wheel (Nazerian R., Korhan O., Shakeri E., 2018), luggage lifting (Joseph L., Standen M., Paungmali A., Kuisma R., Sitilertpisan P., Pirunsan, U., 2020) whole body vibration (Kose Y., Karabayir A.N., Cevikcan E., 2020), task duration (Gómez-Galán M., 2020). Psychosocial factors, such as stress, lack of social support, and low income, also have a significant influence on the development of occupational diseases, including musculoskeletal (Nahorna A. M., Sokolova M. P., Kononova I. G., 2016). Considering the significant number of harmful factors affecting the driver's health when performing the transport work, it was proposed to use a comprehensive criterion based on the calculation of appropriate weight scores (Kee D., 2020). However, as stated in (Hita-Gutiérrez M., Gómez-Galán M., Díaz-Pérez M., Callejón-Ferre Á.-J., 2020), it is important to provide a simple and rapid assessment of ergonomic risks using the Rapid upper limb assessment (RULA) method for driver awareness, development of appropriate rest schedules for managerial decisions. However, this approach does not take into account a number of other hazards that can significantly affect the driver's condition, the reduction of his performance and the development of occupational diseases. Therefore, a slightly improved version of such assessment called Driver Ergonomic Risk Assessment (DERA) has appeared, which allows obtaining a proper result (Bunpot L., Klangduen P., 2019; Hvorost M., Prasolenko O., 2017). This method is based on individual data of employees, exposure to physical and psychosocial factors. At the same time, this approach is aimed at assessing only ergonomic risk and does not allow establishing a complete picture of driver exposure to determine the level of occupational risk of developing occupational diseases.

The conducted analysis of the impact of occupational risks on the driver during transport work fulfillment has revealed several acute problems for society and the transport industry as a whole. One of them is an increase in the number of accidents during the analyzed period due to driver's fault, and the second one is unsatisfactory working conditions of PB drivers, their state of health, and lack of effective control of the mentioned causes.

The aim of this work is to improve the procedure of occupational risk assessment for drivers using the checklist, which takes into account ergonomic, psychosocial, individual, 
hygienic factors.

The object of the study is the impact of occupational risk on the PB driver during passenger transportation.

Subject of the study is the methodology of rapid assessment of occupational risk of a $\mathrm{PB}$ driver.

In order to achieve the goal, the following tasks should be solved:

- to analyze the definition of occupational risk of a PB driver on the basis of the checklist, which takes into account ergonomic, psychosocial, individual and hygienic factors;

- to calculate the value of occupational risk on the basis of the input data, based on the results of the survey with the developed checklist of professional PB drivers;

- to demonstrate the feasibility and necessity of introducing the proposed approach to assess the occupational risk of a PB driver at the motor transport enterprises by the example of the results of the conducted research.

\section{Material and methods}

The assessment of occupational risk of a PB driver is an important component of both the road safety system and the occupational safety. Identification of hazards associated with PB driving, assessment of occupational risks associated with this process are the main elements of planning the preventive measures in the occupational safety management systems of the road transport enterprises. These steps allow prioritization aimed at ensuring appropriate road safety measures. This process requires the formation of appropriate skills and abilities for PB drivers to foresee a certain development of events, followed by the determination of the necessary tools to avoid accidents and reduce the likelihood of occupational diseases.

An important stage on which the further steps and the obtained result depend is the identification of hazards acting on the driver and determining the level of occupational risk. Usually, the information obtained from safety audits, scheduled inspections for compliance with the regulatory requirements, analysis of the causes of accidents, health monitoring of drivers, interviewing and observation of their work is used for this purpose. However, the work of PB driver is referred to the work of a special character, which is connected with increased neuro-emotional strain, and which is fulfilled under conditions of increased risk for his health (Resolution of the Cabinet of Ministers of Ukraine of 17.11.1997 No. 1290). Hence, we can conclude that the main hazards that act on the driver are in the psychosocial and sanitary-hygienic planes. On the other hand, repetition of the same type of movements, monotony of work, uncomfortable working posture are ergonomic hazards, which also require appropriate consideration. Considering the specifics of work, a checklist has been developed (Fig. 1), which allows a quick determining the level of occupational risk by assigning the corresponding scores. It includes an assessment of ergonomic, psychosocial, hygienic and individual factors to determine the overall occupational risk, which is the basis of its distinctiveness from the well-known and wellestablished methods for rapid assessment of employees' work position: Rapid Entire Body Assessment worksheet (REBA), Rapid Upper Limb Assessment (RULA) and Driver Ergonomic Risk Assessment (DERA) rapid assessment of the ergonomic risk of workers.

The development of the proposed checklist is also caused by the need for a versatile rapid assessment of the occupational health risk of the driver to make management decisions aimed at changing his mode of operation or choosing a safer PB or introducing wellness programs for drivers. The checklist is divided into five different zones. The first zone is "Ergonomic factor" that allows a quick assessment of the driver's working posture, taking into account the level of vibration, the magnitude of load on the limbs, the duration of transport work. The zone is conditionally divided into three stages. The first is the evaluation of a shoulder, a forearm and a wrist positioning. The second stage is concerned with determining the position of the body, the head 
and legs. The third stage is the determination of the total score, taking into account the load and duration of the transport work. The number of scores is determined by the corresponding representation of the working position and the coloured rows in the table, which corresponds to the colour of the cells where the scores are specified per positioning of the parts of the body.

The second stage is "Psychosocial factor" has five questions concerning the evaluation of the organization of the production process and is conducted through the prism of the driver's perception. The assessment can be both subjective, when the driver himself puts the scores on the basis of his own feeling, and the objective one - when taking into consideration the data obtained during the certification of workplaces and specified in the relevant cards of working conditions. The questions asked were chosen from the Methodical Recommendations for Certification of Workplaces according to Working Conditions, approved by the Resolution of the Ministry of Labour of Ukraine and the Chief Sanitary Doctor of Ukraine No. 41 of 01.09.1992.

The third stage - "Discomfort factor" is determined through sanitary and hygienic assessment of the driver's working conditions. There are also five questions, which can be answered by putting an appropriate mark, based on the analysis of the impact of harmful factors on the driver.

The fourth stage is the "Individual factor", which contributes to the definition of possible accidents caused by the health condition of the drivers. Its calculation is based on information about the age, body mass index, blood pressure, heart rate and respiratory hold. The data for determining the integral scored index of the biological age of the employees, determined by the method of V.P. Voytenko that is successfully used for assessing the level of health, were taken as a basis for assessing the mentioned factor. In addition, Federal Motor Carrier Safety Administration recommendations were used to certify drivers for health-related accidents occurrence. The last zone on the checklist is provided for summarizing and establishing the overall level of occupational risk.

The occupational risk was assessed among the drivers of PB models "MB Sprinter 411", "Ruta 23", "Bohdan A20111", which are widely represented in the segment of road passenger transportation in the city of Dnipro. Ten drivers at the age of 28 to 45 years with 5 to 20 years of work experience took part in the experiment.

Statistical analysis. The material was processed using an application of a standard Microsoft Office program package - Excel 2010. The obtained data should have normal law of probability distribution, and for their analysis, we mainly used the Student's parametric criteria. The number of observations was sufficient to obtain unbiased estimations of the first two moments: arithmetic mean (M) and root mean square deviation $(\delta)$. The Student's criterion was used to compare the mean values of quantitative indices under normal distribution. The significance level of $p<0.05$ with $95 \%$ reliability was considered reliable.

\section{Results and discussion}

First, physiological indicators of PB driver's health state (systolic blood pressure, heart rate, respiratory hold, body mass index) were determined; the data are given in Table 1.

The next step was to analyze the working conditions of $\mathrm{PB}$ drivers in the cabins of respective PB models, based on the results of workplace assessments. The data are shown in Table 2.

At the same time, the drivers filled the tables on the evaluation of psychosocial and hygienic factors, which were then refined based on the instrumental inspection. Finally, the ergonomic factor was evaluated based on several photos of the drivers' working posture (Fig. 2).

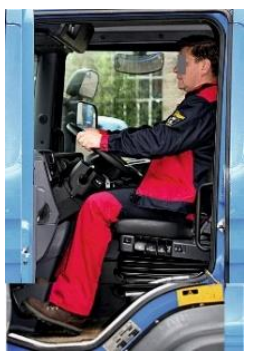

a)

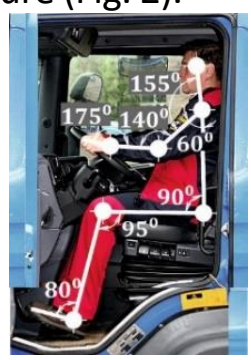

b)
Fig. 2 View of the driver's seat to assess ergonomic factors: a) the location of the driver in the cabin of $\mathrm{PB}$; $b$ ) the location of the driver in the cabin of PB with the applied body structure 
The collected data allowed assessing the checklist (Fig. 3). occupational risk of drivers, using the developed

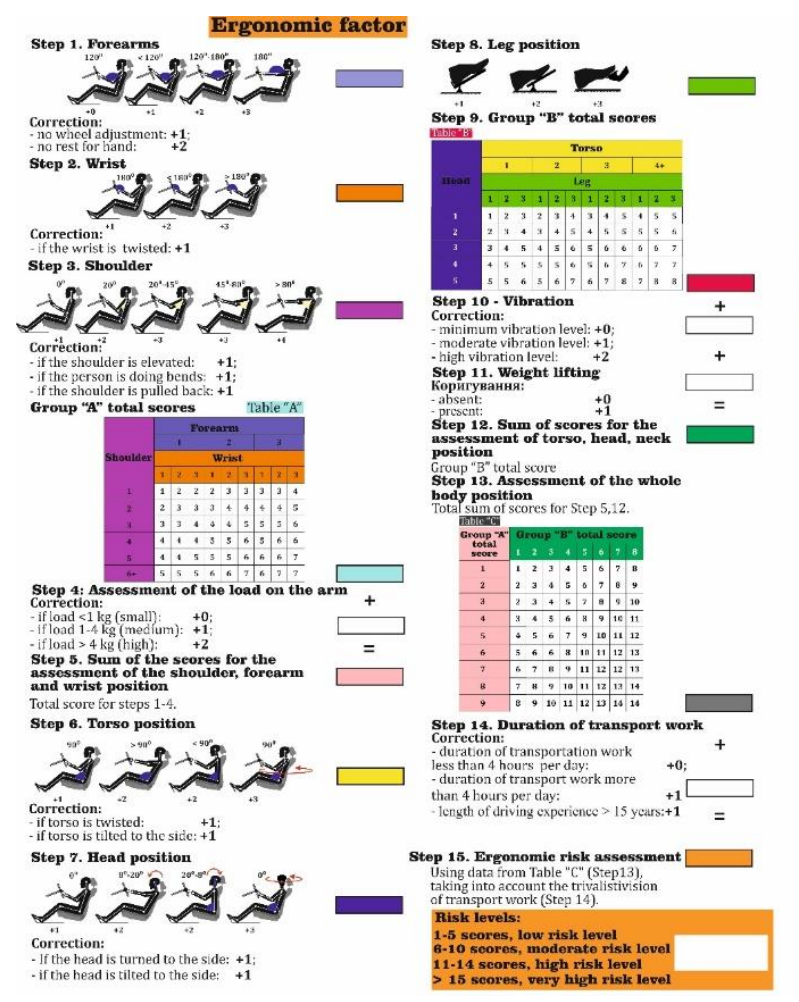

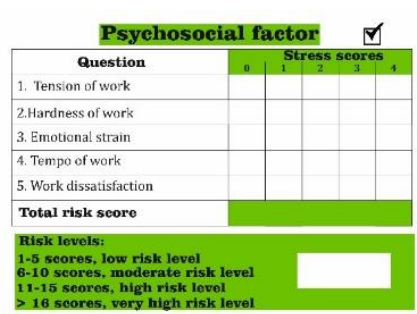
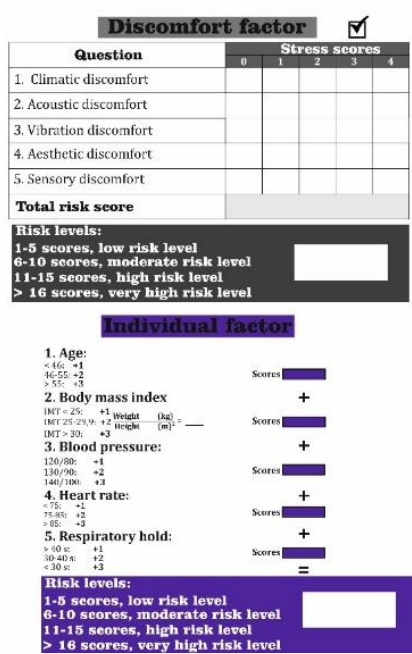

Ergonomic factor

Psychosocial factor

\section{Discomfort factor $+$ \\ Individual factor} $=$

Overall occupational risk assessment of the driver

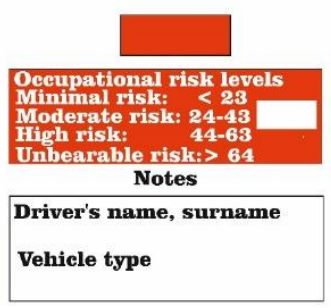

Fig. 1 Checklist for occupational risk assessment of a PB driver

Table 1 - Indicators of basic physiological tests of PB drivers

\begin{tabular}{|c|c|c|c|c|c|c|}
\hline $\begin{array}{c}\text { Number } \\
\text { of } \\
\text { testers } \\
\text { in the } \\
\text { group }\end{array}$ & $\begin{array}{c}\text { Work } \\
\text { experience, } \\
\text { years }\end{array}$ & $\begin{array}{c}\text { Average age } \\
\text { years }\end{array}$ & $\begin{array}{c}\text { Arterial } \\
\text { blood } \\
\text { pressure } \\
\text { systolic, } \\
\mathrm{mm} \mathrm{Hg}\end{array}$ & $\begin{array}{c}\text { Respiratory } \\
\text { hold by the } \\
\text { driver, s }\end{array}$ & $\begin{array}{c}\text { Body } \\
\text { mass } \\
\text { index }\end{array}$ & $\begin{array}{c}\text { Heart rate, } \\
\text { beats/s }\end{array}$ \\
\hline 3 & $5-10$ & $31,4 \pm 0,9$ & $121,4 \pm 2,6$ & $38,9 \pm 3,5$ & 42,2 & 73,6 \\
\hline 4 & $10-15$ & $35,5 \pm 1,4$ & $133,1 \pm 3,2$ & $37,3 \pm 2,1$ & 45,3 & 81,3 \\
\hline 3 & over 15 & $42,4 \pm 0,7$ & $134,8 \pm 2,5$ & $35,6 \pm 2,3$ & 56,1 & 80,6 \\
\hline
\end{tabular}

Table $\mathbf{2}$ - The results of measuring the indicators of harmful production factors that affect the driver of the PB

\begin{tabular}{|c|c|c|c|c|c|}
\hline \multirow[b]{2}{*}{ № } & \multirow[b]{2}{*}{ Indicators } & \multicolumn{3}{|c|}{ Bus model } & \multirow[b]{2}{*}{$\begin{array}{l}\text { MAC (Maximum } \\
\text { allowable } \\
\text { concentration) }\end{array}$} \\
\hline & & $\begin{array}{l}\text { "MB } \\
\text { Sprinter } \\
411 "\end{array}$ & “Ruta 23" & $\begin{array}{l}\text { "Bohdan } \\
\text { A20111" }\end{array}$ & \\
\hline \multirow[t]{2}{*}{1.} & \multicolumn{5}{|c|}{ Noise levels at the workplace } \\
\hline & $\begin{array}{l}\text { Sound pressure level in octane bands } \\
\text { with medium geometric frequencies, } \\
\mathrm{Hz}\end{array}$ & $78,7 \pm 0,55$ & $79,5 \pm 0,45$ & $80,6 \pm 0,84$ & 73 \\
\hline \multirow[t]{5}{*}{2.} & \multicolumn{5}{|c|}{ Microclimatic conditions at the workplace } \\
\hline & \multirow{2}{*}{ Air temperature, ${ }^{\circ} \mathrm{C}$} & \multicolumn{3}{|c|}{ cold period of the year: $+2-+29$} & $+17 \ldots+23$ \\
\hline & & \multicolumn{3}{|c|}{ warm period of the year: $+27-+30$} & $+18 \ldots+27$ \\
\hline & \multirow{2}{*}{ Relative humidity, \% } & \multicolumn{3}{|c|}{ cold period of the year: $16-78$} & 75 \\
\hline & & \multicolumn{3}{|c|}{ warm period of the year: $20-86$} & 65 \\
\hline
\end{tabular}




\begin{tabular}{|c|c|c|c|c|c|}
\hline \multirow[b]{2}{*}{ № } & \multirow[b]{2}{*}{ Indicators } & \multicolumn{3}{|c|}{ Bus model } & \multirow[b]{2}{*}{$\begin{array}{l}\text { MAC (Maximum } \\
\text { allowable } \\
\text { concentration) }\end{array}$} \\
\hline & & $\begin{array}{c}\text { "MB } \\
\text { Sprinter } \\
411 "\end{array}$ & "Ruta 23" & $\begin{array}{l}\text { "Bohdan } \\
\text { A20111" }\end{array}$ & \\
\hline \multirow[t]{3}{*}{3.} & \multicolumn{5}{|c|}{ Levels of dust concentrations in the space of the bus driver's workplace, $\mathrm{mg} / \mathrm{m}^{3}$} \\
\hline & - in the driver's breathing zone & $7,29 \pm 0,35$ & $7,86 \pm 0,43$ & $10,43 \pm 0,51$ & \multirow{2}{*}{6} \\
\hline & - near the floor & $3,11 \pm 0,27$ & $4,49 \pm 0,42$ & $5,76 \pm 0,48$ & \\
\hline \multirow[t]{7}{*}{4.} & \multicolumn{5}{|c|}{ Levels of concentration of harmful chemicals } \\
\hline & $\begin{array}{l}\text { The level of concentration of harmful } \\
\text { substances, } \mathrm{mg} / \mathrm{m}^{2}\end{array}$ & \multicolumn{4}{|c|}{ Nitric oxide } \\
\hline & - in the driver's breathing zone & $2,1 \pm 0,5$ & $2,2 \pm 0,4$ & $2,4 \pm 0,3$ & \multirow{2}{*}{5} \\
\hline & - near the floor & $1,9 \pm 0,2$ & $2,1 \pm 0,2$ & $2,5 \pm 0,4$ & \\
\hline & $\begin{array}{l}\text { The level of concentration of harmful } \\
\text { substances, } \mathrm{mg} / \mathrm{m}^{2}\end{array}$ & \multicolumn{4}{|c|}{ Carbon oxide } \\
\hline & - in the driver's breathing zone & $7,8 \pm 1,4$ & $12,3 \pm 1,4$ & $18,6 \pm 2,1$ & \multirow{2}{*}{20} \\
\hline & - near the floor & $7,2 \pm 1,1$ & $11,2 \pm 1,1$ & $15,7 \pm 1,9$ & \\
\hline \multirow[t]{5}{*}{5.} & \multicolumn{5}{|c|}{ Levels of vibration loading } \\
\hline & The adjusted value of the axis $-Z_{0}$ & 75,8 & 80,5 & 77 & 65 \\
\hline & $\begin{array}{l}\text { Minimum and maximum values axis - } \\
Z_{0}\end{array}$ & $70-80$ & $73-90$ & $74-89$ & 107 \\
\hline & The adjusted value of the axis $-X_{0}, Y_{0}$ & 71,8 & 85 & 86,3 & 62 \\
\hline & $\begin{array}{l}\text { Minimum and maximum values axis - } \\
X_{0}, Y_{0}\end{array}$ & $68,5-76,0$ & $77-93$ & $74-97$ & 116 \\
\hline
\end{tabular}
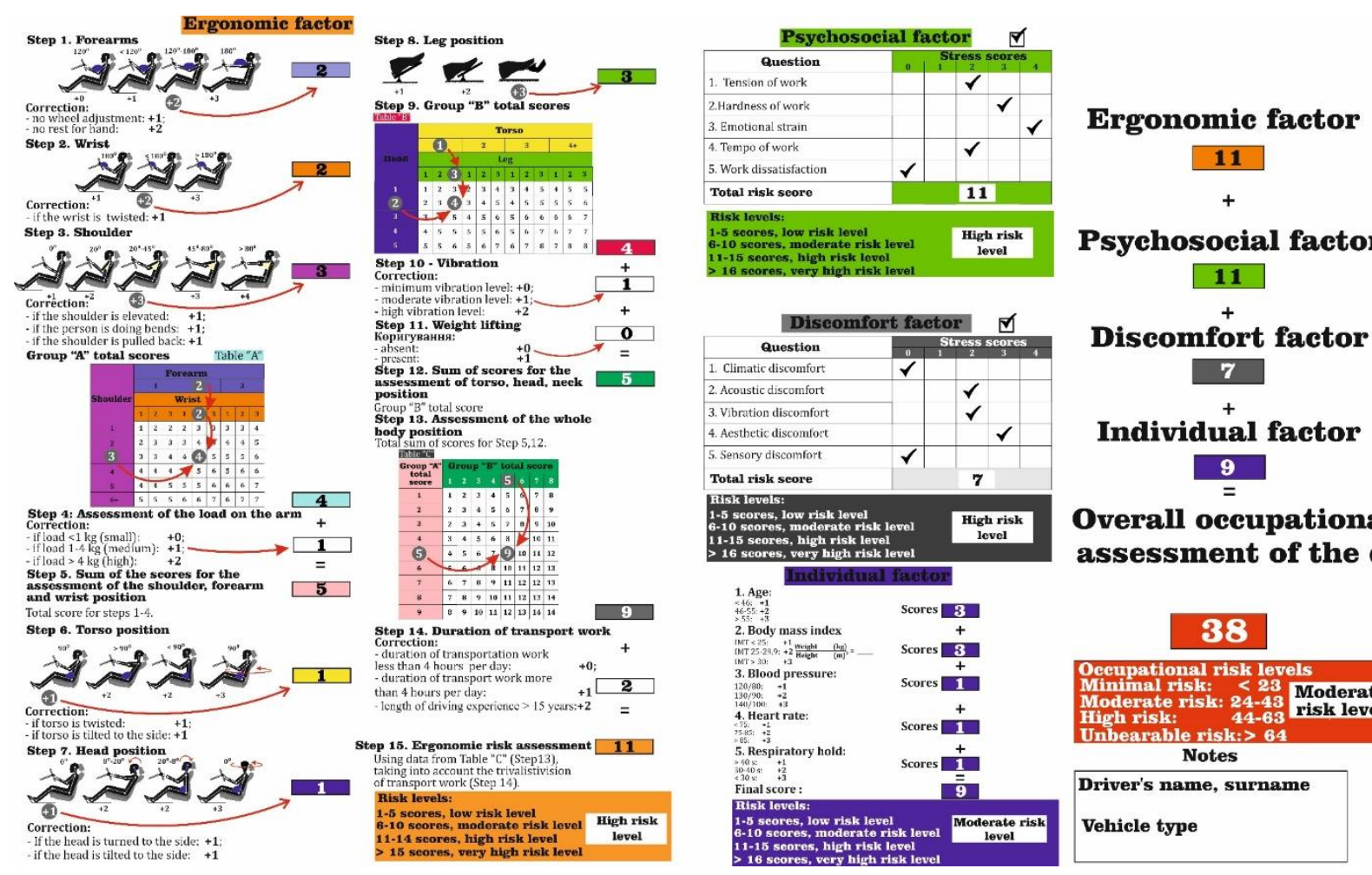

Psychosocial factor
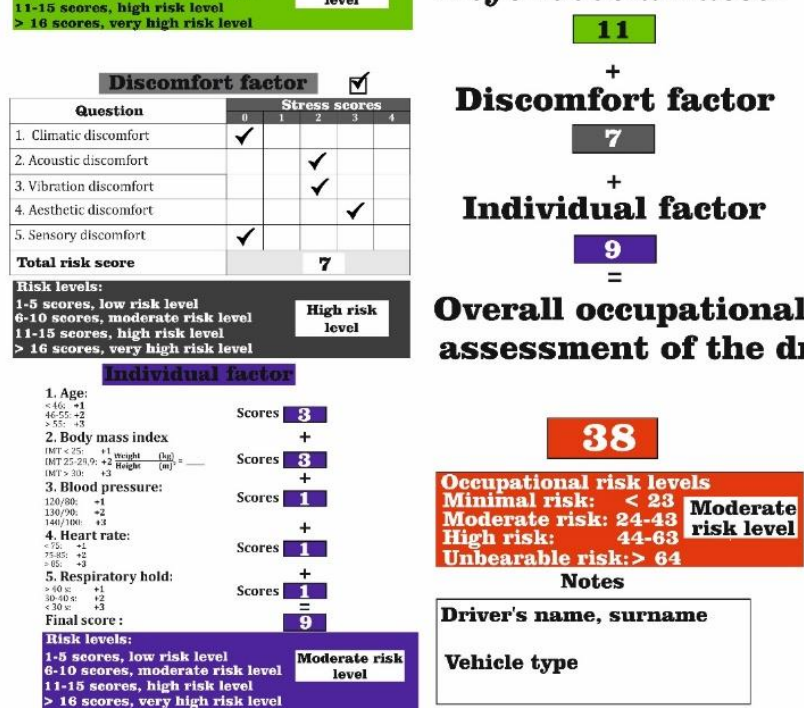

Overall occupational risk assessment of the driver

Fig. 3 The result of calculating the magnitude of occupational risk of the PB driver

As a result, we obtained the levels of occupational risk of drivers that are shown in table 3 . The result allows assessing the impact of each component on the total indicator of occupational risk. This allows defining the most problematic factor, for which further justification of the preventive measures, aimed at its reduction, is carried out. Although in this 
example, the value of risk for drivers of all PBs is approximately at the same level, we can still see that the hygienic factor, which is characterized by exceeding MAC, brings the greatest heterogeneity in the total result, which can be seen from the data in Table 3.

Table 3 - Results of determination of occupational risk level for PB drivers

\begin{tabular}{|c|c|c|c|c|c|}
\hline Bus model & $\begin{array}{c}\text { Ergonomic } \\
\text { factor }\end{array}$ & $\begin{array}{c}\text { Psychosocial } \\
\text { factor }\end{array}$ & $\begin{array}{c}\text { Hygienic } \\
\text { factor }\end{array}$ & $\begin{array}{c}\text { Individual } \\
\text { factor }\end{array}$ & $\begin{array}{c}\text { Total occupational } \\
\text { risk }\end{array}$ \\
\hline "MB Sprinter" & 9 & 11 & 4 & 8 & 32 \\
\hline "Ruta 23" & 11 & 12 & 10 & 9 & 41 \\
\hline "Bohdan A20111" & 11 & 13 & 9 & 9 & 42 \\
\hline
\end{tabular}

The need to assess the occupational risk of PB drivers arose in connection with the introduction in Ukraine of the "Concept of reforming the system of management of occupational safety on the basis of a riskoriented approach", which was reflected in the "National program to improve safety, occupational health and working environment". On the other hand, the need to assess the occupational risks of drivers is due to the desire of some managers of road transport companies to reduce the number of diseases and accidents (Cho K.-T., Shin K., 2016), the main causes of which are considered to be accumulation of fatigue, stress, poor technical condition of vehicles, the influence of weather conditions, etc. (Choi W., Joo K., 2018; Shabanpour R., Auld J., Mohammadian A. K., Stephens T. S., 2017). Therefore, there is a need to ensure continuous monitoring of the factors that can significantly affect the activity of drivers and lead to, among other things, reduced productivity, failure to meet obligations, loss of cargo and others (Bian Y., Yang C., Zhao J.L., Liang L., 2018). The solution to this problem is seen as an assessment of occupational risks to control the situation and justify timely measures, making management decisions. In addition, the approach should be simple and accessible so that drivers can quickly perform the necessary calculations. At the same time, most of the known approaches to occupational risk assessment are based on the search for dose-effect relationships, which require long research and appropriate training. At the same time, most of the well-known approaches to assessing occupational risks are based on the search for dose-effect relationships, which require long-term research and appropriate training. Therefore, based on the recommendations of the standard (IEC 31010:2019 Risk management), a simple method was proposed - a semi-quantitative method for assessing occupational risk, which takes as the priority the hazardous situations based on the predictability of their occurrence and impact on the health of people. Applying this very approach, allows workers to better understand hazards and their consequences. A semi-quantitative analysis of occupational risks provides some numerical characterization of the hazards, their probability of occurrence, and their potential consequences if they occur.

To reduce the effect of occupational risk on the PB driver, it is recommended to modernize the system of medical examinations, which will contribute to the timely detection of diseases (Thiese M. S., Moffitt G., Hanowski R. J., Kales S. N., Porter R. J., Hegmann K. T., 2015). It is recommended to develop a system of motivation to encourage drivers to exercise regularly (Varianou-Mikellidou C., 2019).

At the same time, it is advisable to make physical exercises mandatory in the company before the start of the working day, possibly in combination with a pre-trip medical examination. Now there are a variety of wellness programs that can be implemented in the company (Sendall M., Crane P., Mc Cosker L., Biggs H., Fleming M. L., Rowland B., 2016).

In addition to assessing the physical state of health and development of appropriate wellness programs, it is necessary to pay attention to the psycho-emotional state of the driver by monitoring his biometric data that can be implemented with the help of GPS navigation and continuous operational control of the time 
of the driver being on the route (Wen W., Yamashita A., Asama H., 2017; Arakawaa T., Hibia R., Fujishiro T.A., 2019).

Also, it should be advisable to develop a system of admission to driving which takes into account the training experience of the driver before working independently on the appropriate route. Special attention should be paid to the issues of ergonomic risks and work culture.

It is recommended to strengthen the control over the technical condition of PB, pay attention to the condition of assemblies and units, which may be a source of formation of harmful production factors affecting the driver's health; to provide monitoring of systems and units which operation comfort of the driver depends on; to control in due time the system of heating and air conditioning in the PB cabin, etc.

When renewing or modernizing the vehicle fleet, it is vital to pay attention to the ergonomic characteristics of vehicles, the presence of modern systems that ensure comfortable working conditions and safety of drivers.

\section{Conclusions}

The developed checklist for rapid assessment of occupational risk of drivers, taking into account the influence of harmful production factors, contributing to the manifestation of occupational diseases, has been developed. The peculiarity of this approach is a certain interrelation between the integral criterion of occupational risk of a driver and the indicators characterized by: ergonomic, psychosocial, individual and hygienic factors, formed by working conditions of a driver while transporting the passengers.
The developed checklist can be used at road transport enterprises without any additional equipment and on completion of training for testing. This is a reliable and simple tool for assessing the drivers' occupational risk. The level of occupational risk of each factor affecting the driver can be easily assessed. The DERA method is an important factor to stimulate personal improvement and a useful tool for the PB driver, as it is possible to implement measures to reduce occupational risk.

\section{References}

Arakawaa T., Hibia R., Fujishiro T.A. (2019). Psychophysical assessment of a driver's mental state in autonomous vehicles. Transportation Research Part A: Policy and Practice. №124. P. 587-610. DOI: 10.1016/j.tra.2018.05.003.

Bian Y., Yang C., Zhao J.L., Liang L. (2018). Good drivers pay less: A study of usage-based vehicle insurance models. Transportation Research Part A: Policy and Practice. №107, P. 20-34. DOI: 10.1016/j.tra.2017.10.018

Bunpot L., Klangduen P. (2019). The development of the Driver Ergonomic Risk Assessment (DERA) for assessing the risk factors for professional driver. IOP Conf. Series: Materials Science and Engineering. P. 505, 012148. DOI: 10.1088/1757899X/505/1/012148.

Cho K.-T., Shin K. (2016). Fingerprinting Electronic Control Units for Vehicle Intrusion
Detection. USENIX Security Symposium, Austin, TX. P. 911-927.

Choi W., Joo K., Jo H.J., Park M.C., Lee D.H. (2018). Voltageids: Low-Level Communication Characteristics for Automotive Intrusion Detection System. IEEE Transactions on Information Forensics and Security. №13(8). P. 2114-2129. DOI: 10.1109/TIFS.2018.2812149

Council Directive 89/391/EEC of 12 June 1989 on the introduction of measures to encourage improvements in the safety and health of workers at work. Official Journal of the European Union L 183, 29/6/1989. P. 1-8.

Deryugin O. V., Cheberyachko S. I., Tretyak O. O., Cheberyachko, I. M. (2018). Determination of bus drivers' biological age. Pedagogics, psychology, medical-biological problems of physical training and sports. №22(2). P. 7785. DOI: 10.15561/18189172.2018.0203. 
Feng Z., Zhan J., Wang C., Ma C., Huang, Z. (2018). The association between musculoskeletal disorders and driver behaviors among professional drivers in China. International Journal of Occupational Safety and Ergonomics. №26(3). P. 551-561. DOI: $10.1080 / 10803548.2018 .1482088$.

Golinko V., Cheberyachko S., Deryugin O., Tretyak O. Dusmatova, O. (2020). Assessing risks of occupational diseases in passenger bus drivers. Safety and Health at Work. №11(4). P. 543-549. DOI: 10.1016/j.shaw.2020.07.005.

Gómez-Galán M., Callejón-Ferre Á.-J., PérezAlonso J., Díaz-Pérez M., Carrillo-Castrillo J.A. (2020). Musculoskeletal Risks: RULA Bibliometric Review. International Journal of Environmental Research and Public Health. №17(12). P. $4354 . \quad$ DOI: 10.3390/ijerph17124354.

Hita-Gutiérrez M., Gómez-Galán M., Díaz-Pérez M., Callejón-Ferre Á.-J. (2020). An Overview of REBA Method Applications in the World. International Journal of Environmental Research and Public Health. №17(8), P. 2635. DOI: 10.3390/ijerph17082635.

Hvorost M., Prasolenko O. (2017). Vplyv faktoriv dorozhn'oho rukhu na emotsiynyy stan vodiya [Influence of road traffic factors on the emotional state of the driver]. Scientific and technical collection "Municipal economy of cities". №137, S. 49-54. [in Ukrainian].

IEC 31010:2019 Risk management - Risk assessment techniques. 2019. $264 \mathrm{P}$.

Joseph L., Standen M., Paungmali A., Kuisma R., Sitilertpisan P., Pirunsan, U. (2020). Prevalence of musculoskeletal pain among professional drivers: A systematic review. Journal of Occupational Health. №62, 1-17. DOI: 10.1002/1348-9585.12150.

Kee D. (2020). An empirical comparison of OWAS, RULA and REBA based on selfreported discomfort. International Journal of Occupational Safety and Ergonomics. №26(2). P. 285-295. DOI: 10.1080/10803548.2019.1710933.

Kose Y., Karabayir A.N., Cevikcan E. (2020). The Quick Exposure Check (QEC) Model Proposal
Based on Fuzzy Logic for Work-Related Musculoskeletal Risk Assessment. In: Kahraman C., Cebi S., Cevik Onar S., Oztaysi B., Tolga A., Sari, I. Intelligent and Fuzzy Techniques in Big Data Analytics and Decision Making. INFUS 2019. Advances in Intelligent Systems and Computing. № 1029. Springer, Cham. DOI: 10.1007/978-3-030-23756-1_12. Lebedeva T.L., Gurov S.V., Petrov V.A., Chorny Yu.O. (2016). Vyvchennya stanu zdorov"ya vodiyiv taksi za rezul'tatamy anketnoho opytuvannya, [Taxi drivers' health state survey based on the results of questionnaire survey]. Actual problems of transport medicine. №2(44). S. 67-73. [in Ukrainian].

Lococo K.H., Stutts J., Sifrit K.J., Staplin, L. (2017). Medical review practices for driver licensing, Volume 3: Guidelines and processes in the United States (Report No. DOT HS 812 402). Washington, DC: National Highway Traffic Safety Administration, $650 \mathrm{P}$.

Mestry S., Shroff R. (2018). Prevalence of Low Back Pain in Car Drivers. International Journal of Science and Research. №7(426). P. 11011104. DOI: $10.21275 / A R T 20194108$.

Nahorna A.M., Sokolova M.P., Kononova I.G. (2016). Profesiyna zakhvoryuvanist' medychnykh pratsivnykiv yak medykosotsial'na problema [Occupational morbidity of medical workers in Ukraine as a medical and social problem]. Ukrainian Journal of Occupational Health. №2(47). S. 3-16. DOI: 10.33573/ujoh2016.02.003. [in Ukrainian].

Nazerian R., Korhan O., Shakeri E. (2018). Workrelated musculoskeletal discomfort among heavy truck drivers. International Journal of Occupational Safety and Ergonomics. №26(2). P. 233-244. DOI: 10.1080/10803548.2018.1433107.

Sendall M., Crane P., McCosker L., Biggs H., Fleming M.L., Rowland B. (2016). Workplace interventions to improve truck drivers' health knowledge, behaviours and self-reported outcomes. Road and Transport Research. №25(1). P. 31-43.

Shabanpour R., Auld J., Mohammadian A.K., Stephens T.S. (2017). Developing a Platform to Analyze Behavioral Impacts of Connected 
Automated Vehicles at the National Level. Conference Transportation Research Board 96th Annual Meeting. Washington DC, United States, P. 17-06283.

Thiese M.S., Moffitt G., Hanowski R.J., Kales S.N., Porter R.J., Hegmann K.T. (2015). Commercial Driver Medical Examinations: Prevalence of Obesity. Comorbidities, and Certification Outcomes. Journal of Occupational and Environmental Medicine. №57(6). P. 659665. DOI: 10.1097/JOM.0000000000000422

Varianou-Mikellidou C., Boustras G., Dimopoulos C., Wybo J.L., Guldenmund F.W., Nicolaidou O., Anyfantis I. (2019). Occupational health and safety management in the context of an ageing workforce. Safety
Science. №116. P. 231-244 DOI: 10.1016/j.ssci.2019.03.009

Wen W., Yamashita A., Asama H. (2017). Measurement of the perception of control during continuous movement using electroencephalography. Frontiers in Human Neuroscience. №11, P. $392 . \quad$ DOI: 10.3389/fnhum.2017.00392

Yosef T., Belachew A., Tefera, Y. (2019). Magnitude and Contributing Factors of Low Back Pain among Long Distance Truck Drivers at Modjo Dry Port, Ethiopia: A CrossSectional Study. Journal of Environmental and Public Health. Article ID 6793090, DOI: 10.1155/2019/6793090. 